\title{
MOTIF PENGGUNAAN RADIO MORA OLEH KOMUNITAS PENDENGAR AMOR DI KOTA BANDUNG JAWA BARAT
}

\author{
Henny Sri Mulyani R \\ Fakultas Ilmu Komunikasi Universitas Padjadjaran \\ henny.sri.mulyani@unpad.ac.id
}

\begin{abstract}
The power of the radio is based on the direct power, penetration, and attraction of the radio. Radio trends today have a specific segmentation or type of format based on a particular content selection. In turn make the radio station has its own trademark. Radio Mora is one of the radio media that has specific content that is about the law information as the main menu of the broadcast. Community listeners of Mora Radio named Members of Mora (Amor). The existence of this community shows that they consciously have a motive in using the media in addition to other media for the fulfillment of information needs. Therefore, the researcher is interested to see how the motive use of Mora radio media by Amor community to meet the information needs in the field of law. The research method used is descriptive quantitative. The results show that Amor community members have an information motive consisting of looking for news, getting guidance, knowing various opinions, studying law with very high category. Motives of personal identity include consisting of finding behavioral models, improving self-understanding, supporting personal values are high. Motives of interaction and social integration consist of knowing other people's circumstances, finding chats, helping social roles, connecting with society etc. As well as the motive of entertainment consists of forgetting the daily problems, relax, enjoyment of the soul, fill the spare time and distribute emotion quite high.
\end{abstract}

Keywords: Radio program, community, radio usage motive

\begin{abstract}
ABSTRAK
Kekuatan radio didasarkan pada daya langsung, daya tembus, dan daya tarik yang dimiliki radio. Trend radio di masa kini memiliki segmentasi yang spesifik atau jenis format yang didasarkan pada pilihan konten tertentu. Pada gilirannya menjadikan stasiun radio memiliki ciri khasnya masing-masing. Radio Mora adalah salah satu media radio yang memiliki konten spesifik yaitu informasi bidang hukum sebagai menu utama siarannya. Komunitas pendengar Radio Mora bernama Anggota Mora (Amor). Keberadaan komunitas ini menunjukkan bahwa mereka secara sadar mempunyai motif dalam menggunakan media tersebut selain media lain untuk pemenuhan kebutuhan informasi. Oleh karena itu peneliti tertarik untuk melihat bagaimana motif penggunaan media Radio Mora oleh komunitas Amor untuk pemenuhan kebutuhan informasi dalam bidang hukum. Metode penelitian yang digunakan adalah deskriptif kuantitatif. Hasil penelitian menunjukkan anggota komunitas Amor memiliki motif informasi yang terdiri dari mencari berita, mendapat bimbingan, mengetahui ragam pendapat, belajar hukum dengan katagori sangat tinggi. Motif identitas pribadi diantaranya terdiri dari menemukan model prilaku,
\end{abstract}


meningkatkan pemahaman diri, menunjang nilai pribadi tergolong tinggi. Motif interaksi dan integrasi sosial terdiri dari mengetahui keadaan orang lain, menemukan obrolan, membantu peran sosial, terhubung dengan masyarakat dll. Serta motif hiburan terdiri dari melupakan masalah sehari-hari, bersantai, kenikmatan jiwa, mengisi waktu luang dan menyalurkan emosi tergolong tinggi.

\section{Kata-kata Kunci: Program radio, komunitas, motif penggunaan radio}

\section{PENDAHULUAN}

Radio sebagai salah satu bentuk media massa mendapat julukan sebagai the fifth estate (Ardianto, 2007:128). Julukan ini muncul mengingat kekuatan radio sebagai teknologi baru dianggap punya pengaruh kuat seperti pada Perang Dunia II, kekuatan radio tersebut didasarkan pada daya langsung, daya tembus, dan daya tarik yang dimiliki radio.

Daya langsung radio berkaitan dengan proses penyusunan dan penyampaian pesan pada pendengarnya yang relatif cepat dibandingkan media massa lainnya. Daya tembus radio berkaitan dengan pendistribusian informasi yang lebih ringkas dan tidak terlalu terbebani oleh lokasi khalayak. Sementara daya tarik radio terdapat pada sifatnya yang serba hidup berkat tiga unsur yang ada padanya yaitu musik, kata-kata, dan efek suara.

Kekuatan radio siaran dalam memengaruhi khalayak sudah teruji di lapangan misalkan ketika 1970-an Pemerintah Republik Indonesia mempunyai program tentang keluarga berencana yang harus disosialisasikan pada masyarakat, maka salah satu upaya sosialisasi stasiun radio siaran digunakan untuk menyebarluaskan informasi mengenai keluarga berencana. Pada tahun 2000-an rencana pemerintah akan dilakukan pengalihan penggunaan minyak tanah ke gas elpiji, salah satu media yang digunakan untuk menyampaikan pesan tersebut adalah radio siaran.

Trend radio dimasa kini memiliki segmentasi yang spesifik atau jenis format yang didasarkan pada pilihan konten tertentu. Pada gilirannya menjadikan stasiun radio memiliki ciri khasnya masing-masing. Radio Mora adalah salah satu media radio yang memiliki konten spesifik, yaitu bidang hukum sebagai menu utama siarannya. Pada umumnya radio siaran lain hanya sebagian kecil menyiarkan bidang hukum dari konten keseluruhannya.

Menurut General Manager Radio Mora, Mora Saragih, Radio Mora memiliki visi untuk membangun komunikasi konstruktif di dalam masyarakat, yaitu dapat saling memberi 
manfaat tentang kesadaran kehidupan bermasyarakat, berbangsa, bernegara dalam kerangka mengerti dan taat hukum demi menuju kehidupan yang lebih baik. Hal tersebut diwujudkan dalam positioning Radio Mora sebagai the law and justice station. Mora membidik tujuan untuk mengembangkan pemahaman masyarakat dalam ranah hukum.

Keberadaan Radio Mora menarik untuk diteliti sehubungan dengan kondisi hukum yang ada dewasa ini. Banyak pihak menilai pelaksanaan hukum di Indonesia belum maksimal. Hukum seperti pisau yang tajam di bawah tetapi tumpul di atas (Editorial Majalah Readers Digest Indonesia edisi September 2011, hal 5). Maksudnya, ketika berhadapan dengan masyarakat yang lemah, hukum seolah diterjemahkan seperti tertulis sehingga para pelaku kejahatan sekecil apapun mendapat ganjaran. Sementara kepada pelanggar dari kalangan kuat baik secara finansial maupun akses terhadap kekuasaan hukum bisa diatur agar menguntungkan mereka.

Padahal demi terciptanya kepastian hukum, semua orang haruslah memiliki kedudukan yang sama di hadapan hukum. Jadi setiap orang bisa terjerat hukum dan setiap orang memiliki hak yang sama sewaktu berhadapan dengan hukum. Hukum di Indonesia ada untuk mengatur kehidupan tiap individu dalam negeri ini sehingga tercipta keteraturan dan ketertiban di dalamnya (Editorial Majalah Readers Digest Indonesia edisi September 2011, hal 5).

Menurut Mora Saragih, di sinilah Radio Mora menampilkan perannya sebagai media mengemban misi untuk menjadi media yang berguna bagi rakyat sebagai media advokasi yang bersedia membantu masyarakat menerima aspirasi, aduan, maupun keluhan masyarakat seraya senantiasa berupaya untuk meningkatkan kesadaran hukum masyarakat. Hal ini dilakukan dengan menyediakan program-program yang menonjolkan diskusi interaktif yang membahas realitas sosial dalam masyarakat dengan perspektif hukum.

Program di Radio Mora diasuh oleh penyiar radio yang kebanyakan merupakan praktisi di bidang hukum. Dari 14 program siaran yang ada terdapat lima program siaran utama yang berkaitan dengan masalah hukum. Dalam penelitian ini lima program itulah yang masuk kategori program informasi hukum. Kelima program tersebut secara rutin mengudara dari Senin hingga Sabtu sejak pukul 06.00 hingga 21.00 atau mengudara selama 12 jam. Kelima program tersebut adalah : 
1. Somasi (Sorotan Masalah dan Situasi) yang membahas berbagai informasi dan permasalahan publik Kota Bandung dengan perspektif hukum.

2. Saksi (Saran Komentar dan Informasi) membahas permasalahan regional maupun nasional yang sedang hangat dengan perspektif hukum.

3. Kasasi (Kasus dari Sana Sini) yang membahas kasus-kasus hukum secara detail sekaligus menjadi ruang untuk berkonsultasi masalah hukum.

4. Motif (Mora Interaktif) yang merupakan program interaktif dengan topik mengenai kasus hukum yang spesifik.

5. Eksekusi (Ekstra Sekunder dan Informasi) yang merupakan program interaktif dengan topik mengenai isu-isu yang sedang berkembang di masyarakat. Sesekali menghadirkan narasumber terkait dengan isu yang dibahas.

Radio Mora memiliki komunitas pendengar yang bernama Anggota Mora (Amor). Berdasarkan data terdapat 720 anggota Amor di Kota Bandung. Keberadaan komunitas ini menunjukkan bahwa mereka secara sadar menggunakan media tersebut, selain media lain, untuk pemenuhan kebutuhan informasi. Oleh karena itu, peneliti tertarik untuk melihat bagaimana penggunaan media Radio Mora oleh komunitas Amor untuk pemenuhan kebutuhan informasi dalam bidang hukum.

Segmentasi pendengar Radio Mora adalah pendengar berusia 27 tahun ke atas yang terdapat pada rentang SES (status ekonomi sosial) B1, B2, dan C. Dengan asumsi bahwa golongan masyarakat inilah yang sering kali berhadapan dengan permasalahan hukum yang beragam dan menyentuh banyak bidang kehidupan seperti masalah pertanahan, perkawinan, hingga perniagaan. Selain itu, Radio Mora memiliki wilayah jangkauan siaran Kota Bandung dan sekitarnya.

\section{KERANGKA PEMIKIRAN}

Uses and Gratifications theory dikemukakan bahwa khalayak yang aktif dalam menggunakan media untuk memenuhi kebutuhannya untuk mencapai tujuan tertentu. Studi pada bidang ini memusatkan perhatian pada penggunaan (uses) media untuk mendapatkan kepuasan (gratifications) atas kebutuhan seseorang. Menurut Katz 
dikemukakan bahwa adanya kebutuhan

psikologis dan sosial yang menimbulkan harapan tertentu dari media massa yang membawa pada pola terpaan media yang berlainan dan menimbulkan pemenuhan kebutuhan secara kognitif, afektif, dan konatif. Teori ini menyelidiki berbagai macam kebutuhan individu yang berasal dari media.

\section{Anteseden $\longrightarrow$ Motif $\longrightarrow$ Penggunaan Media $\longrightarrow$ Efek \\ - V. Individual kognitif jumlah waktu yg kepuasan \\ - V. Lingkungan diversi digunakan pengetahuan \\ Personal id macam isi \\ Hub.dg isi}

Gambar 1 Kebutuhan Individu dari Media

Sumber : Rakhmat (2007)

Radio sebagai media massa mempunyai ciri-ciri yang khas jika dibandingkan dengan media komunikasi massa lainnya. Romli (2004: 22-23) menjabarkan karakteristik radio antara lain:

1. Auditori. Radio adalah suara untuk didengar, karenanya isi siaran bersifat sepintas lalu dan tidak dapat diulang. Pendengar tidak mungkin menoleh ke belakang sebagaimana pembaca koran yang bisa kembali ke pada tulisan yang sudah dibaca atau mengulang bacaan.

2. Transmisi. Proses penyebarluasannya atau disampaikannya kepada pendengar melalui pemancaran (transmisi).

3. Mengandung gangguan. Seperti timbul tenggelam (fading) dan gangguan teknis (channel noise factor).

4. Theatre of mind. Radio mencipta gambaran dalam imajinasi pendengar dengan kekuatan kata dan suara. Pendengar hanya bisa membayangkan dalam imajinasinya apa yang dikemukakan penyiar bahkan tentang sosok penyiarnya sendiri.

5. Identik dengan musik. Radio adalah sarana hiburan termurah dan tercepat sehingga menjadi media utama untuk mendengarkan musik. Dalam hal musik radio memiliki daya surprise seketika atau memberi kejutan, karena pendengar biasanya tidak tahu lagu apa yang disajikan. Berbeda dengan memutar kaset yang sudah dapat diketahui urutan lagunya.

Apabila dibandingkan dengan ragam media massa lainnya karakteristik radio memiliki keunggulan sebagai sebuah media komunikasi massa. Keunggulan radio menurut Romli (2004 : 23-25) antara lain:

1. Cepat dan langsung. Sarana tercepat, lebih cepat dari koran ataupun televisi dalam penyampaian informasi kepada publik tanpa melalui proses yang rumit dan butuh waktu banyak 
seperti siaran televisi atau sajian media cetak. Hanya melalui telepon, reporter radio dapat secara langsung menyampaikan berita atau melaporkan peristiwa yang ada di lapangan.

2. Akrab. Radio adalah alat yang akrab dengan pemiliknya. Suara penyiar hadir di dekat pendengar dan pembicaraannya menyentuh aspek pribadi.

3. Hangat. Paduan kata-kata, musik, dan efek suara dalam siaran radio mampu mempengaruhi emosi pendengar. Pendengar akan bereaksi atas kehangatan suara penyiar dan sering kali berpikir bahwa penyiar adalah seorang teman bagi mereka.

4. Sederhana. Tidak rumit, tidak banyak pernik bagi pengelola maupun pendengar.

5. Tanpa batas. Siaran radio menembus batas-batas geografi, demografis, SARA (suku, agama, ras, dan antargolongan), juga kelas sosial.

6. Murah. Dibandingkan dengan berlangganan media cetak atau harga pesawat televisi, radio relatif jauh lebih murah. Pendengar tidak dipungut bayaran sepeser pun untuk mendengarkan siaran radio.

7. Bisa mengulang. Radio memiliki kesementaraan alami (transient nature) sehingga berkemampuan mengulang informasi yang sudah disampaikan secara cepat.

8. Fleksibel. Siaran radio bisa dinikmati sambil mengerjakan hal lain atau tanpa mengganggu aktivitas yang lain, seperti memasak, mengemudi, belajar, dan membaca.

Karakteristik radio selain memiliki kekuatan juga memiliki kelemahan apabila dibandingkan dengan ragam media massa lainnya. Menurut Romli (2004: 25-26) karakteristik radio memiliki beberapa kelemahan, di antaranya:

1. Selintas. Siaran radio cepat hilang dan gampang dilupakan. Pendengar tidak bisa mengulang apa yang didengarkannya, tidak bisa seperti pembaca koran yang bisa mengulang bacaannya dari awal tulisan.

2. Global. Sajian informasi radio bersifat global, tidak detail, misalnya penggunaan angkaangka yang sering kali dibulatkan.

3. Keterbatasan waktu. Waktu siaran radio relatif terbatas hanya 24 jam sehari berbeda dengan surat kabar yang bisa menambah jumlah halaman dengan bebas.

4. Berlalu linier. Program disajikan dan dinikmati pendengar berdasarkan urutan yang sudah ada, tidak bisa meloncat-loncat. Berbeda dengan surat kabar, pembaca bisa langsung ke halaman tengah, akhir, atau langsung ke rubrik yang disukai.

5. Mengandung gangguan. Seperti timbul tenggelam dan gangguan teknis channel noise factor.

Motif merupakan penyebab penggunaan media yang terletak dalam lingkungan sosial terutama psikologis yang dirasakan sebagai masalah. Dalam hal ini media digunakan sebagai pemuas kebutuhan (McQuail, 1996: 217). Motif penggunaan dalam penelitian ini diperiksa berdasarkan kerangka motif yang disarankan McQuaill (1996: 72) yaitu motif informasi, motif identitas 
pribadi, motif interaksi dan integrasi sosial, serta motif hiburan.

$$
\text { McQuail (1996: 72-73) }
$$

menjelaskan bahwa motif dapat diukur menggunakan kategori motif pengonsumsian media yang mana terdiri dari hal-hal berikut:

1. Motif informasi; pengguna memiliki motif informasi apabila mereka:

a. Mencari berita tentang peristiwa dan kondisi yang berkaitan dengan lingkungan terdekat, masyarakat dan dunia.

b. Mencari bimbingan menyangkut berbagai masalah praktis, pendapat dan hal-hal yang berkaitan dengan penentuan pilihan.

c. Memuaskan rasa ingin tahu dan minat umum.

d. Belajar, pendidikan diri sendiri.

e. Memperoleh rasa damai melalui penambahan pengetahuan.

2. Motif identitas pribadi; pengguna dikatakan memiliki motif identitas pribadi apabila mereka:

a. Menemukan penunjang nilainilai pribadi.

b. Menemukan model perilaku

c. Mengidentifikasi diri dengan nilai-nilai lain (dalam media)

d. Meningkatkan pemahaman tentang diri sendiri.

3. Motif integrasi dan interaksi sosial; dikatakan memiliki motif integrasi dan interaksi sosial apabila mereka:

a. Memperoleh pengetahuan tentang keadaan orang lain, empati sosial. b. Mengidentifikasi diri dengan orang lain dan meningkatkan rasa memiliki.

c. Menemukan bahan percakapan dan interaksi sosial.

d. Memperoleh teman selain manusia.

e. Membantu menjalankan peran sosial.

f. Memungkinkan seseorang untuk dapat menghubungi sanak keluarga, teman dan masyarakat.

4. Motif hiburan; dikatakan memiliki motif hiburan apabila mereka:

a. Melepaskan diri atau terpisah dari permasalahan.

b. Bersantai

c. Memperoleh kenikmatan jiwa dan estetis.

d. Mengisi waktu

e. Penyaluran emosi.

\section{METODE PENELITIAN}

Sugiyono

mendefinisikan metode penelitian kuantitatif sebagai sebuah metode penelitian yang berdasarkan pada filsafat positivisme, digunakan untuk meneliti populasi atau sampel tertentu, pengumpulan data menggunakan instrumen penelitian, analisis data bersifat kuantitatif/statistik dengan tujuan untuk menguji hipotesis yang telah ditetapkan.

Singarimbun dan Effendi (1989: 42) menyebutkan, penelitian survei digunakan untuk maksud eksploratif, deskriptif, eksplanatif, evaluasi, prediksi, 
operasional, dan pengembangan indikator-indikator sosial. Lebih jauh disebutkan penelitian survei dilakukan melalui proses seperti pengumpulan data lapangan, menggambarkan dan menganalisis data dengan bantuan analisis statistika yang relevan dan selanjutnya dibuat kesimpulan tentang arti data tersebut. Penelitian ini dimaksudkan untuk mengukur dengan cermat fenomena sosial tertentu dengan mengembangkan konsep dan menghimpun fakta tanpa melakukan pengujian hipotesis.

Populasi yang dijadikan objek dalam penelitian ini adalah seluruh anggota komunitas pendengar Radio Mora yang berada di Kota Bandung. Jumlah anggota komunitas pendengar adalah sebanyak 720 orang. Ukuran sampel dalam penelitian ini dihitung dengan menggunakan rumus Yamane (Rahmat, 2007: 82) diperoleh sebanyak 88 orang anggota.

\section{HASIL DAN PEMBAHASAN}

Motif Informasi Penggunaan Radio Mora oleh Komunitas Pendengar Amor di Kota Bandung Jawa Barat

\section{Tabel 1}

Motif Informasi Komunitas Pendengar Amor

\begin{tabular}{|c|c|c|c|c|c|c|}
\hline Pernyataan & $\begin{array}{l}\text { Sangat } \\
\text { setuju }\end{array}$ & Setuju & Ragu-ragu & $\begin{array}{l}\text { Tidak } \\
\text { setuju }\end{array}$ & $\begin{array}{l}\text { Sangat } \\
\text { tidak setuju }\end{array}$ & $\begin{array}{l}\text { Jumlah } \\
(\%)\end{array}$ \\
\hline $\begin{array}{l}\text { Mencari } \\
\text { berita seputar } \\
\text { dunia hukum }\end{array}$ & $\begin{array}{l}41 \\
(46,6 \%)\end{array}$ & $\begin{array}{l}45 \\
(51,2 \%)\end{array}$ & $\begin{array}{l}1 \\
(1,1 \%)\end{array}$ & $\begin{array}{l}1 \\
(1,1 \%)\end{array}$ & $\begin{array}{l}0 \\
(0,0)\end{array}$ & $\begin{array}{l}88 \\
(100,0)\end{array}$ \\
\hline $\begin{array}{l}\text { Mendapat } \\
\text { bimbingan } \\
\text { praktis }\end{array}$ & $\begin{array}{l}39 \\
(44,3 \%)\end{array}$ & $\begin{array}{l}44 \\
(50,0 \%)\end{array}$ & $\begin{array}{l}5 \\
(5,7 \%)\end{array}$ & $\begin{array}{l}0 \\
(0,0 \%)\end{array}$ & $\begin{array}{l}0 \\
(0,0 \%)\end{array}$ & $\begin{array}{l}88 \\
(100,0)\end{array}$ \\
\hline $\begin{array}{l}\text { Mengetahui } \\
\text { beragam } \\
\text { pendapat }\end{array}$ & $\begin{array}{l}35 \\
(39,8 \%)\end{array}$ & $\begin{array}{l}53 \\
(60,2 \%)\end{array}$ & $\begin{array}{l}0 \\
(0,0 \%)\end{array}$ & $\begin{array}{l}0 \\
(0,0 \%)\end{array}$ & $\begin{array}{l}0 \\
(0,0 \%)\end{array}$ & $\begin{array}{l}88 \\
(100,0\end{array}$ \\
\hline $\begin{array}{l}\text { Memuaskan } \\
\text { rasa ingin } \\
\text { tahu }\end{array}$ & $\begin{array}{l}31 \\
(35,3)\end{array}$ & $\begin{array}{l}53 \\
(60,2)\end{array}$ & $\begin{array}{l}4,0 \\
(4,5 \%)\end{array}$ & $\begin{array}{l}0 \\
(0,0 \%)\end{array}$ & $\begin{array}{l}0 \\
\text { (o) }\end{array}$ & $\begin{array}{l}88 \\
(100,0)\end{array}$ \\
\hline $\begin{array}{l}\text { Belajar } \\
\text { hukum }\end{array}$ & $\begin{array}{l}33 \\
(37,5 \%)\end{array}$ & $\begin{array}{l}46 \\
(52,3 \%)\end{array}$ & $\begin{array}{l}5 \\
(5,7 \%)\end{array}$ & $\begin{array}{l}4 \\
(4,5 \%)\end{array}$ & $\begin{array}{l}0 \\
(0,0 \%)\end{array}$ & $\begin{array}{l}88 \\
(100,0)\end{array}$ \\
\hline $\begin{array}{l}\text { Mencari } \\
\text { kedamaian }\end{array}$ & $\begin{array}{l}13 \\
(14,8 \%)\end{array}$ & $\begin{array}{l}58 \\
(65,9 \%)\end{array}$ & $\begin{array}{l}16 \\
(18,2 \%)\end{array}$ & $\begin{array}{l}1 \\
(1,1 \%)\end{array}$ & $\begin{array}{l}0 \\
(0,0 \%)\end{array}$ & $\begin{array}{l}88 \\
(100,0)\end{array}$ \\
\hline
\end{tabular}


Sumber: hasil penelitian

Berdasarkan Tabel 1 menunjukkan bahwa komunitas pendengar Amor pada umumnya mempunyai motif informasi untuk mencari berita seputar dunia hukum, mendapat bimbingan praktis, mengetahui beragam pendapat, memuaskan rasa ingin tahu, belajar hukum, dan mencari kedamaian.

Dalam masyarakat modern ini ada beragam cara untuk memperoleh informasi. Media memainkan peranan penting dalam penyebaran informasi. Menurut Kusumaningrat dan Kusumaningrat (2006:41) hal tersebut terkait erat dengan nilai-nilai ideal yang diemban oleh media, yakni memberikan informasi yang selengkapnya kepada khalayak ramai, membantu khalayak mendapatkan haknya untuk mendapatkan informasi yang benar dan lengkap.

Menurut Masduki (2001: 3) ada beberapa tingkatan peran sosial yang diemban radio dalam kapasitasnya sebagai media publik atau yang dikenal dalam konsep radio for society. Dalam konsep tersebut radio tidak hanya berperan sebagai media penyampai informasi dari satu pihak ke pihak lain tetapi radio pun dapat digunakan sebagai sarana untuk mempertemukan dua pendapat yang berbeda sehingga radio dapat dijadikan sebuah ruang diskusi untuk mencari solusi bersama yang saling menguntungkan. Ruang itulah yang dimanfaatkan pendengar untuk membahas beragam pendapat yang ada.

Sementara menurut Astuti (2008: 137) diskusi yang terjadi di radio memenuhi tujuan-tujuan seperti:

1. Mencari solusi. Di sini diskusi menjadi semacam forum curah gagasan.

2. Menjelaskan permasalahan, menggali, dan menganalisis diskusi menjadi sarana untuk menyampaikan informasi yang lebih mendalam dari sekadar berita.

3. Menginformasi. Diskusi menjadi ajang mencari kejelasan di antara pelbagai spekulasi.

4. Katarsis. Forum diskusi juga berguna untuk melepaskan tekanan atau katarsis yaitu melepaskan kekesalan dan kegeraman pada suatu hal yang dianggap tidak benar.

Ruang diskusi tersebut pada Radio Mora difasilitasi melalui program-program yang memungkinkan pendengar dapat melakukan dialog interaktif seperti Somasi, Kasasi, Motif, dan Saksi.

Adapun skor total untuk motif informasi yang diperoleh dari data penelitian adalah 2.261 dan berdasarkan perhitungan Rentang Kuartil (RK) berada pada kategori sangat tinggi. Oleh karena itu dapat dikatakan bahwa motif informasi pada anggota komunitas 
pendengar Amor di Kota Bandung menjalankan salah satu fungsinya untuk tergolong sangat tinggi. Hal ini memberikan informasi kepada pendengar bermakna bahwa Radio Mora telah dengan baik.

\section{Motif Identitas Pribadi Penggunaan Radio Mora oleh Komunitas Pendengar Amor di Kota Bandung Jawa Barat}

Tabel 2

Motif Identitas Pribadi Komunitas Pendengar Amor

\begin{tabular}{|c|c|c|c|c|c|c|}
\hline Pernyataan & $\begin{array}{l}\text { Sangat } \\
\text { setuju }\end{array}$ & Setuju & Ragu-ragu & $\begin{array}{l}\text { Tidak } \\
\text { setuju }\end{array}$ & $\begin{array}{l}\text { Sangat } \\
\text { tidak setuju }\end{array}$ & $\begin{array}{l}\text { Jumlah } \\
(\%)\end{array}$ \\
\hline $\begin{array}{l}\text { Mendapat } \\
\text { penunjang nilai- } \\
\text { nilai pribadi }\end{array}$ & $\begin{array}{l}11 \\
(12,5 \%)\end{array}$ & $\begin{array}{l}64 \\
(72,2 \%)\end{array}$ & $\begin{array}{l}13 \\
(14,8 \%)\end{array}$ & $\begin{array}{l}0 \\
(0,0 \%)\end{array}$ & $\begin{array}{l}0 \\
(0,0 \%)\end{array}$ & $\begin{array}{l}88 \\
(100,0)\end{array}$ \\
\hline $\begin{array}{l}\text { Menemukan } \\
\text { model prilaku }\end{array}$ & $\begin{array}{l}11 \\
(12,5 \%)\end{array}$ & $\begin{array}{l}62 \\
(70,5 \%)\end{array}$ & $\begin{array}{l}13 \\
(14,8 \%)\end{array}$ & $\begin{array}{l}2 \\
(2,3 \%)\end{array}$ & $\begin{array}{l}0 \\
(0,0 \%)\end{array}$ & $\begin{array}{l}88 \\
(100,0)\end{array}$ \\
\hline $\begin{array}{l}\text { Mengidentifikasi } \\
\text { diri dengan nilai } \\
\text { lain (dalam } \\
\text { media) }\end{array}$ & $\begin{array}{l}17 \\
(19,3 \%)\end{array}$ & $\begin{array}{l}67 \\
(76,1 \%)\end{array}$ & $\begin{array}{l}2 \\
(2,3 \%)\end{array}$ & $\begin{array}{l}0 \\
(0,0 \%)\end{array}$ & $\begin{array}{l}2 \\
(2,3 \%)\end{array}$ & $\begin{array}{l}88 \\
(100,0)\end{array}$ \\
\hline $\begin{array}{l}\text { Meningkatkan } \\
\text { pemahaman } \\
\text { tentang diri } \\
\text { sendiri }\end{array}$ & $\begin{array}{l}8 \\
(9,1 \%)\end{array}$ & $\begin{array}{l}70 \\
(79,5 \%)\end{array}$ & $\begin{array}{l}8 \\
(9,1 \%)\end{array}$ & $\begin{array}{l}2 \\
(2,3 \%)\end{array}$ & $\begin{array}{l}0 \\
(0,0 \%)\end{array}$ & $\begin{array}{l}88 \\
(100,0)\end{array}$ \\
\hline
\end{tabular}

Sumber : hasil penelitian

Berdasarkan Tabel 2 menunjukkan bahwa komunitas pendengar Amor pada umumnya mempunyai motif identitas pribadi untuk mendapatkan penunjang nilai-nilai pribadi, menemukan model prilaku, mengidentifikasi diri dengan nilai-nilai lain dalam media dan meningkatkan pemahaman tentang diri sendiri.

Maslow dalam Goble (2009 : 154) menyatakan bahwa manusia memiliki kebutuhan untuk mengaktualisasikan diri. Mereka yang mengaktualisasikan diri lebih dikendalikan oleh pemahaman diri mereka sendiri dan kebutuhan-kebutuhan dasar mereka daripada nilai-nilai di luar diri mereka. Ketika berhadapan dengan nilai-nilai yang berbeda, orang-orang itu menghadapi sebuah serangan. Untuk bertahan, mereka membutuhkan segala hal yang dianggap perlu untuk menunjang nilai-nilai yang mereka yakini. Dalam konteks inilah media 
massa ditempatkan sebagai salah satu sarana yang dapat digunakan untuk menunjang nilai-nilai pribadi. Tabel 2 menunjukkan bahwa mayoritas komunitas pendengar Amor memiliki tujuan tersebut.

Sebagai sebuah media, Radio Mora menjalankan fungsi penyebaran nilai. Menurut Ardianto (2007: 58) fungsi penyebaran nilai atau sosialisasi mengacu kepada cara di mana individu mengadopsi perilaku dan nilai kelompok. Media memberikan model peran yang dapat diamati dan harapan untuk menirunya.

Respons positif menunjukkan bahwa Radio Mora dijadikan sebagai salah satu sarana untuk mengenal nilainilai yang ada di luar diri. Menurut McQuail (1996: 53), media massa adalah cermin yang memantulkan citra masyarakat terhadap masyarakat itu sendiri. Dengan kata lain, media massa berfungsi sebagai jendela pengalaman yang meluaskan pandangan individu dan memungkinkan seseorang untuk mampu memahami apa yang terjadi di lingkungan sekitar.

Adapun skor total untuk motif identitas pribadi yang diperoleh dari data penelitian adalah 1.405. Nilai tersebut berada di antara nilai Kuartil yang tergolong pada kategori tinggi. Oleh karena itu, dapat dikatakan bahwa motif identitas pribadi pada anggota pendengar komunitas Amor di Kota Bandung terhadap siaran Radio Mora tergolong tinggi yang bermakna bahwa program siaran yang dikumandangkan Radio Mora baik atau bermanfaat bagi khalayak pendengar.

Motif Integrasi dan Interaksi Sosial Penggunaan Radio Mora oleh Komunitas Pendengar Amor di Kota Bandung Jawa Barat

Tabel 3

Motif Integrasi dan Interaksi Sosial Komunitas Pendengar Amor

\begin{tabular}{|c|c|c|c|c|c|c|}
\hline Pernyataan & $\begin{array}{l}\text { Sangat } \\
\text { setuju }\end{array}$ & Setuju & Ragu-ragu & $\begin{array}{l}\text { Tidak } \\
\text { setuju }\end{array}$ & $\begin{array}{l}\text { Sangat } \\
\text { tidak setuju }\end{array}$ & $\begin{array}{l}\text { Jumlah } \\
(\%)\end{array}$ \\
\hline $\begin{array}{l}\text { Mengetahui } \\
\text { keadaan orang } \\
\text { lain }\end{array}$ & $\begin{array}{l}4 \\
(4,5 \%)\end{array}$ & $\begin{array}{l}54 \\
(61,4 \%)\end{array}$ & $\begin{array}{l}24 \\
(27,3 \%)\end{array}$ & $\begin{array}{l}6 \\
(6,8 \%)\end{array}$ & $\begin{array}{l}0 \\
(0,0 \%)\end{array}$ & $\begin{array}{l}88 \\
(100,0)\end{array}$ \\
\hline $\begin{array}{l}\text { Meningkatkan } \\
\text { rasa memiliki }\end{array}$ & $\begin{array}{l}9 \\
(10,3 \%)\end{array}$ & $\begin{array}{l}72 \\
(81,8 \%)\end{array}$ & $\begin{array}{l}5 \\
(5,7 \%)\end{array}$ & $\begin{array}{l}1 \\
(1,1 \%)\end{array}$ & $\begin{array}{l}1 \\
(1,1 \%)\end{array}$ & $\begin{array}{l}88 \\
(100,0)\end{array}$ \\
\hline $\begin{array}{l}\text { Menemukan } \\
\text { bahan obrolan }\end{array}$ & $\begin{array}{l}5 \\
(5,7 \%)\end{array}$ & $\begin{array}{l}44 \\
(50,0 \%)\end{array}$ & $\begin{array}{l}31 \\
(35,2 \%)\end{array}$ & $\begin{array}{l}6 \\
(6,8 \%)\end{array}$ & $\begin{array}{l}2 \\
(2,3 \%)\end{array}$ & $\begin{array}{l}88 \\
(100,0)\end{array}$ \\
\hline
\end{tabular}




\begin{tabular}{|c|c|c|c|c|c|c|}
\hline $\begin{array}{l}\text { Teman selain } \\
\text { manusia }\end{array}$ & $\begin{array}{l}9 \\
(10,3 \%)\end{array}$ & $\begin{array}{l}47 \\
(53,4 \%)\end{array}$ & $\begin{array}{l}24 \\
(27,3 \%)\end{array}$ & $\begin{array}{l}8 \\
(9,1 \%)\end{array}$ & $\begin{array}{l}0 \\
(0,0 \%)\end{array}$ & $\begin{array}{l}88 \\
(100,0)\end{array}$ \\
\hline $\begin{array}{l}\text { Membantu } \\
\text { peran sosial }\end{array}$ & $\begin{array}{l}11 \\
(12,5 \%)\end{array}$ & $\begin{array}{l}66 \\
(75 \%)\end{array}$ & $\begin{array}{l}10 \\
(11,4 \%)\end{array}$ & $\begin{array}{l}0 \\
(0,0 \%)\end{array}$ & $\begin{array}{l}1 \\
(1,1 \%)\end{array}$ & $\begin{array}{l}88 \\
(100,0)\end{array}$ \\
\hline $\begin{array}{l}\text { Menghubungi } \\
\text { sanak saudara }\end{array}$ & $\begin{array}{l}3 \\
(3,4 \%)\end{array}$ & $\begin{array}{l}24 \\
(27,3 \%)\end{array}$ & $\begin{array}{l}23 \\
(26,1 \%)\end{array}$ & $\begin{array}{l}35 \\
(39,8 \%)\end{array}$ & $\begin{array}{l}3 \\
(3,4 \%)\end{array}$ & $\begin{array}{l}88 \\
(100,0)\end{array}$ \\
\hline $\begin{array}{l}\text { Menghubungi } \\
\text { teman }\end{array}$ & $\begin{array}{l}4 \\
(4,5 \%)\end{array}$ & $\begin{array}{l}25 \\
(28,4 \%)\end{array}$ & $\begin{array}{l}22 \\
(25 \%)\end{array}$ & $\begin{array}{l}34 \\
(38,6 \%)\end{array}$ & $\begin{array}{l}3 \\
(3,5 \%)\end{array}$ & $\begin{array}{l}88 \\
(100,0)\end{array}$ \\
\hline $\begin{array}{l}\text { Terhubung } \\
\text { dengan } \\
\text { masyarakat }\end{array}$ & $\begin{array}{l}7 \\
(8,0 \%)\end{array}$ & $\begin{array}{l}38 \\
(43,2 \%)\end{array}$ & $\begin{array}{l}28 \\
(31,8 \%)\end{array}$ & $\begin{array}{l}15 \\
(17,0 \%)\end{array}$ & $\begin{array}{l}\mathrm{O} \\
(0,0 \%)\end{array}$ & $\begin{array}{l}88 \\
(100,0)\end{array}$ \\
\hline
\end{tabular}

Sumber: hasil Penelitian

Tabel 3 menunjukkan bahwa pada umumnya komunitas pendengar Amor mempunyai motif integrasi dan interaksi sosial komunitas pendengar Amor untuk mengetahui keadaan orang lain, meningkatkan rasa memiliki, menemukan bahan obrolan, teman selain manusia, membantu peran sosial, menghubungi sanak saudara, menghubungi teman, dan terhubung dengan masyarakat.

Dibalik kemampuan media untuk menyampaikan informasi, terdapat fungsi media untuk memenuhi kebutuhan sosial (social utility). Masduki (2001: 3) mengatakan bahwa ada empat tingkatan peran sosial yang diemban radio dalam kapasitasnya sebagai media publik. Pertama, radio mengemban peran sebagai penyampai informasi. Kedua, radio berfungsi sebagai sarana mobilisasi pendapat publik. Ketiga, radio adalah sarana untuk mempertemukan dua pendapat berbeda. Keempat, radio adalah sarana untuk mengikat kebersamaan dalam semangat kemanusiaan.

Pada fungsi keempat itulah radio memenuhi kebutuhan individu untuk memuaskan motif empati sosial. Dengan mengetahui keadaan orang lain, seorang individu meningkatkan rasa memiliki di tengah-tengah suatu komunitas.

Sementara itu dalam Ardianto (2007: 16) dikatakan bahwa media memiliki fungsi pertalian (linkage). Media dapat menyatukan anggota masyarakat yang beragam sehingga membentuk pertalian berdasarkan kepentingan dan minat yang sama tentang sesuatu. Individu-individu yang memiliki kepentingan sama tetapi terpisah secara geografis dapat dihubungkan melalui media.

Berdasarkan pengamatan peneliti, setiap program siaran Radio Mora selalu ada pendengar yang terlibat. Fasilitas yang digunakan pada saat itu adalah 
telepon atau SMS. Tidak hanya sekadar bertanya, beberapa pendengar terkadang berkirim salam di ruang siaran. Melalui fasilitas itulah, beberapa pendengar menjalin keterhubungan dengan sanak saudara, teman, juga masyarakat Kota Bandung.

Adapun skor total untuk motif integrasi dan interaksi sosial yang diperoleh dari data penelitian adalah
2.461. Nilai tersebut berada di antara nilai Kuartil yang tergolong pada kategori tinggi. Oleh karena itu, dapat dikatakan bahwa motif integrasi dan interaksi sosial pada anggota pendengar komunitas Amor di Kota Bandung terhadap siaran Radio Mora tergolong tinggi. Hal itu bermakna bahwa program siaran yang dikumandangkan Radio Mora beik atau bermanfaat bagi khalayak pendengar.

\section{Motif Hiburan Penggunaan Radio Mora oleh Komunitas Pendengar Amor di Kota Bandung Jawa Barat}

Tabel 4

Motif Hiburan Komunitas Pendengar Amor

\begin{tabular}{|c|c|c|c|c|c|c|}
\hline Pernyataan & $\begin{array}{l}\text { Sangat } \\
\text { setuju }\end{array}$ & Setuju & Ragu-ragu & $\begin{array}{l}\text { Tidak } \\
\text { setuju }\end{array}$ & $\begin{array}{l}\text { Sangat } \\
\text { tidak } \\
\text { setuju }\end{array}$ & $\begin{array}{l}\text { Jumlah } \\
(\%)\end{array}$ \\
\hline Bersantai & $\begin{array}{l}18 \\
(20,5 \%)\end{array}$ & $\begin{array}{l}47 \\
(53,4 \%)\end{array}$ & $\begin{array}{l}10 \\
(11,4 \%)\end{array}$ & $\begin{array}{l}12 \\
(13,6 \%)\end{array}$ & $\begin{array}{l}1 \\
(1,1 \%)\end{array}$ & $\begin{array}{l}88 \\
(100,0)\end{array}$ \\
\hline $\begin{array}{l}\text { Melupakan } \\
\text { masalah } \\
\text { sehari-hari }\end{array}$ & $\begin{array}{l}7 \\
(8,0 \%)\end{array}$ & $\begin{array}{l}48 \\
(54,5 \%)\end{array}$ & $\begin{array}{l}19 \\
(32,6 \%)\end{array}$ & $\begin{array}{l}11 \\
(12,5 \%)\end{array}$ & $\begin{array}{l}3 \\
(3,4 \%)\end{array}$ & $\begin{array}{l}88 \\
(100,0)\end{array}$ \\
\hline $\begin{array}{l}\text { Kenikmatan } \\
\text { jiwa dan } \\
\text { estetis }\end{array}$ & $\begin{array}{l}14 \\
(15,9 \%)\end{array}$ & $\begin{array}{l}49 \\
(55,3 \%)\end{array}$ & $\begin{array}{l}22 \\
(25,0)\end{array}$ & $\begin{array}{l}3 \\
(3,4 \%)\end{array}$ & $\begin{array}{l}0 \\
(0,0 \%)\end{array}$ & $\begin{array}{l}88 \\
(100,0)\end{array}$ \\
\hline $\begin{array}{l}\text { Mengisi waktu } \\
\text { luang }\end{array}$ & $\begin{array}{l}26 \\
(29,5 \%)\end{array}$ & $\begin{array}{l}46 \\
(52,3 \%)\end{array}$ & $\begin{array}{l}11 \\
(12,5 \%)\end{array}$ & $\begin{array}{l}5 \\
(5,7 \%)\end{array}$ & $\begin{array}{l}0 \\
(0,0 \%)\end{array}$ & $\begin{array}{l}88 \\
(100,0)\end{array}$ \\
\hline $\begin{array}{l}\text { Menyalurkan } \\
\text { emosi }\end{array}$ & $\begin{array}{l}11 \\
(12,5 \%)\end{array}$ & $\begin{array}{l}35 \\
(39,8 \%)\end{array}$ & $\begin{array}{l}24 \\
(27,3 \%)\end{array}$ & $\begin{array}{l}16 \\
(18,2 \%)\end{array}$ & $\begin{array}{l}2 \\
(2,3 \%)\end{array}$ & $\begin{array}{l}88 \\
(100,0)\end{array}$ \\
\hline
\end{tabular}

Sumber: Hasil Penelitian

Tabel 4 menunjukkan bahwa pada umumnya komunitas pendengar Amor mempunyai motif hiburan untuk melupakan masalah sehari-hari, mendapat kenikmatan jiwa dan estetis, mengisi waktu luang serta menyalurkan emosi.

Bersantai merupakan bagian dari motif hiburan (diversion). Menurut Ardianto (2007: 25) hiburan adalah 
kebutuhan dasar pada manusia. Pada media massa, pemuasan kebutuhan hiburan ini ditempuh dengan beberapa cara di antaranya stimulation atau pencarian untuk mengurangi rasa bosan, relaxation santai) atau mengurangi ketegangan, dan emotional release atau pelepasan emosi. Di Radio Mora beberapa program didesain untuk memenuhi kebutuhan akan hiburan ini antara lain program Sapa Mora, Amor Memories, Konpensi.

Menurut Ardianto (2007: 25) salah satu alasan yang mendasari penggunaan media massa adalah pelarian (withdrawal). Orang tidak hanya menggunakan media untuk tujuan santai tapi menggunakan media untuk keluar dari kepenatan rutinitas sehari-hari. Selain itu dengan mendengarkan radio dapat memperoleh kenikmatan jiwa dengan mendengarkan musik yang sesuai dengan selera. Kenikmatan jiwa atau estetis bisa pula diartikan sebagai salah satu jalan untuk melepaskan diri dari ketegangan yang dalam Ardianto (2007: 25) disebut sebagai pelarian atau tekanan.

Adapun skor total untuk motif hiburan yang diperoleh dari data penelitian adalah 1.638. Nilai tersebut berada di antara nilai Kuartil yang tergolong pada kategori tinggi. Oleh karena itu dapat dikatakan bahwa motif hiburan pada anggota pendengar komunitas Amor di Kota Bandung terhadap siaran Radio Mora tergolong tinggi. Hal ini bermakna bahwa program siaran yang dikumandangkan Radio Mora baik atau bermanfaat bagi khalayak pendengar.

\section{SIMPULAN}

Motif penggunaan Radio Mora oleh anggota komunitas pendengar Amor di Kota Bandung umumnya tergolong tinggi. Dari empat motif yang diidentifikasi, motif pencarian informasi tergolong sangat tinggi. Hal ini berkaitan dengan kebutuhan pendengar untuk memahami informasi dan seluk beluk dunia hukum yang dianggap penting dalam kehidupan bermasyarakat.

Motif identitas diri pada anggota komunitas pendengar Amora berada pada kategori tinggi. Dalam hal ini, Radio Mora dianggap mampu memberikan model perilaku dan bantuan bagi responden untuk memahami dirinya sendiri.

Motif integrasi dan interaksi sosial dapat disimpulkan bahwa pendengar memiliki tujuan untuk berinteraksi dengan masyarakat Kota Bandung sekaligus meningkatkan rasa 
memiliki sebagai warga Kota Bandung

melalui penggunaan Radio Mora.

Motif hiburan juga menunjukkan indikasi yang sama, Radio Mora sebagai media massa dianggap dapat membantu untuk bersantai dan melepaskan diri untuk sementara dari rutinitas kehidupan sehari-hari.

\section{UCAPAN TERIMA KASIH}

Ucapan terimakasih peneliti haturkan kepada pengelola Radio Mora, terutama General Manager Radio Mora, Mora Saragih. Ucapan terima kasih peneliti haturkan pula pada komunitas pendengar yang bernama Anggota Mora (Amor) di Bandung, Jawa Barat. Terima kasih pada pihak lain yang selama ini telah membantu proses penyelesaian penelitian ini.

\section{DAFTAR PUSTAKA}

Ardianto, Elvinaro, Lukiati Komala dan Siti Karlina. 2007. Komunikasi Massa: Suatu Pengantar. Bandung: Simbiosa Rekatama Media.

Astuti, Santi Indra. 2008. Jurnalisme Radi: Teori dan Praktik. Bandung: Simbiosa Rekatama Media.

Bungin, Burhan. 2010. Metodologi Penelitian Kuantitatif. Jakarta: Kencana Prenada Media Grup.

Effendy, Onong Uchyana. 1991. Radio Siaran: Teori dan Praktek.
Bandung: Penerbit Mandar Maju. .2003. Ilmu, Teori, dan Filsafat Komunikasi. Bandung: Citra Aditya Bakti.

Gobble, Frank G. 2009. Mazhab Ketiga: Psikologi Humanistik Abraham Maslow. Yogyakarta: Kanisius.

Kusumaningrat, Hikmat dan Purnama Kusumanungrat. 2006. Jurnalistik: Teori dan Praktik. Bandung: Remaja Rosdakarya.

Marzuki, Peter Mahmud. 2009. Pengantar Ilmu Hukum. Jakarta: Kencana Prenada Media Grup.

Masduki. 2001. Jurnalistik Radio: Menata Profesionalisme Reporter dan Penyiar. Yogyakarta: LKiS

McQuail, Dennis. 1996. Teori Komunikasi Massa: Suatu Pengantar. Jakarta: Erlangga.

Morissan, Andy Corry Wardhani dan Farid Hamid. 2010. Teori Komunikasi Massa. Bogor: Ghalia Indonesia

Mulyana, Deddy. 2005. Ilmu Komunikasi: Suatu Pengantar. Bandung: Remaja Rosdakarya.

Rahmat, Jalaluddin. 2005. Psikologi Komunikasi. Bandung: Remaja Rosdakarya. 2007. Metode Penelitian Komunikasi. Bandung: Remaja Rosdakarya.

Romli, Asep Syamsul. 2004. Broadcast Journalism. Bandung: Nuansa.

Sugiyono. 2010. Metode Penelitian Kuantitatif, Kualitatif dan $R \&$ $D$. Bandung: Alfabeta

\section{Sumber Lain:}

Editorial Majalah Readers Digest

Indonesia edisi September 2011, hal 5 